Economics Development Analysis Journal 9(1)(2020)

\title{
The Effectivenes of Rehabilitation Uninhabitable House Program Service
}

\section{Rizki Nafisa ${ }^{1,}$ Etty Soesilowati ${ }^{\circledR}$}

${ }^{1,2}$ Economics Development Department, Economics Faculty, Universitas Negeri Semarang

\begin{tabular}{|c|c|}
\hline Article Info & Abstract \\
\hline $\begin{array}{l}\text { Hisrtory of Article } \\
\text { Received October } 2019 \\
\text { Accepted December } 2019 \\
\text { Pusblished February } 2020\end{array}$ & $\begin{array}{l}\text { This research aims to know the implementation of service distribution, effectiveness rehabilitation } \\
\text { of unhabitable house service program in Brebes Regency. This research is a quantitative research } \\
\text { and data collected through observation, interview, questionnaire and documentation. The samples } \\
\text { of the research were } 100 \text { respondens spreaded in Brebes. The collection of data was analyzed using } \\
\text { descriptive approach. The result of the research showed that there were five steps of the distribution } \\
\text { mechanism of the service based on the Central Java Governor Regulation Number } 48 \text { Year } 2017 \text { as } \\
\text { follows planning, funding, implementing, monitoring, evaluating and reporting. Based on the data } \\
\text { analysis showed the uneffectiveness of result in aiming the purpose of presentation with the } 55.94 \% \text {. } \\
\text { Satisfaction variable towards the program showed the unsatisfaction with the } 57.84 \% \text {, and the target } \\
\text { of variable accuracy showed that the targets have been accomplished with } 84.07 \% \text {. This research } \\
\text { suggested a guidance towards the receiver of the service on the proposal making, the optimalisation } \\
\text { work of the executant of the program, control and Evaluate in order to be fixed and implemented a } \\
\text { based on the guidelines provide so that the purpose of the program can be accomplished. }\end{array}$ \\
\hline
\end{tabular}

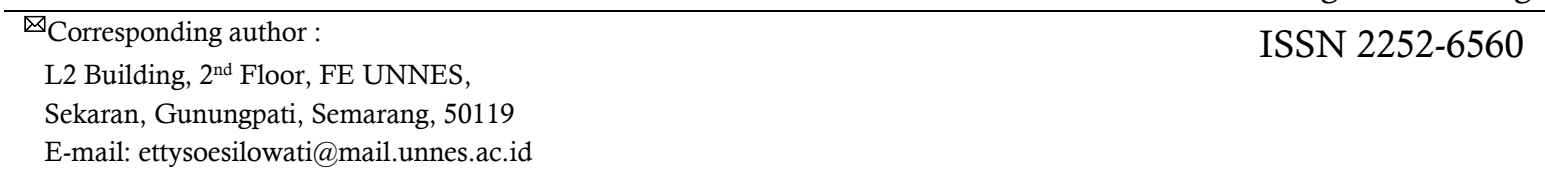

\section{INTRODUCTION}


Referring to the commitment of SDGs and 2030 which is to reduce by half so that its target to $6.64 \%$. Thus, every year the reduction of poverty at least by $0.44 \%$ per year for 15 years. On the other hand, when viewed from the nominal number of poor people in Central Java, Indonesia ranks second after East Java province. In 2018 the number of poor people in Central Java amounted to 3.8972 million inhabitants. This shows that the central Java remains one of the pockets of poverty in Indonesia.

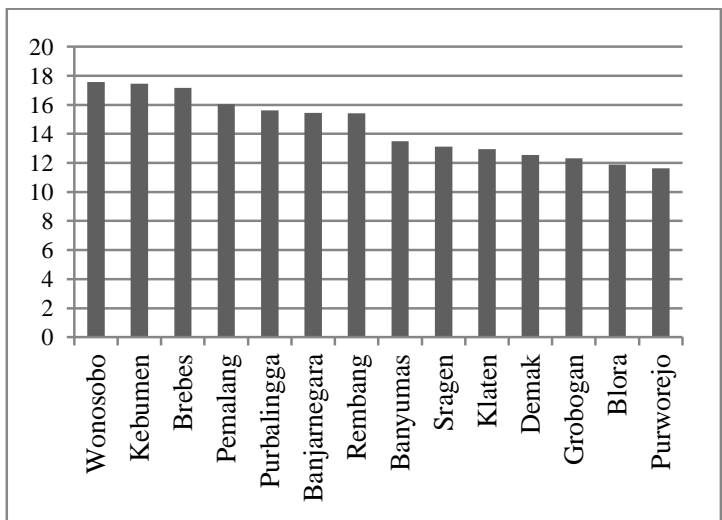

Figure 1. Priority Areas Poverty in Central Java (\%)

Source: Central Bureau of Statistics Republic of Indonesia

Brebes is one of the districts that get into the red zone of poverty, the poverty percentage rate above the national and provincial poverty to become a priority area for poverty reduction in Central Java. The number of poor people in Brebes is the largest in Central Java, which amounted to $1,796,004$ inhabitants with a composition of poor people amounted to $17.17 \%$ in 2018. The number of homes uninhabitable in Brebes based on Pemutakhiran Basis Data Terpadu (PBDT) in 2015 there were 63471 units, then occurred handling fee of 9855 housing units so that the number of Rumah Tidak Layak Huni (RTLH) be 53616 units in 2016. in 2017 and 2018 the number of RTLH Brebes increased to 55 296 units and amounted to 135975 units in 2018. The number of RTLH Brebes are presented in the following diagram.

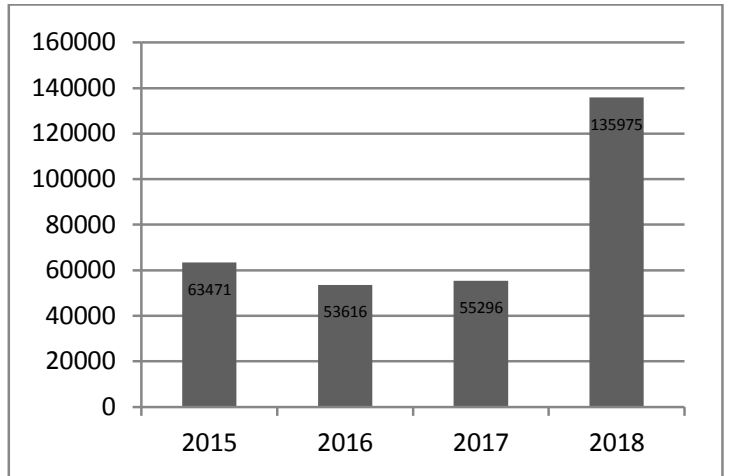

Figure 2. Based PBDT RTLH Brebes in Central Java Province (Thousand)

Source: Housing and Settlement Department Brebes Regency

Of the 17 districts in Brebes Regency that has the most number RTLH District of Bulakamba, District Wanasari and Brebes District. Handling problems uninhabitable houses in Brebes has been done by the relevant government parties that assistance from the State Budget, the budget 1, the budget 2, and CSR and other related parties. The number of uninhabitable houses that have been handled by the Provincial Government of Central Java Brebes in the year 201 through the financial aid funds are presented in the following table.

Table 1. Handling recapitulation Brebes RTLH budget Funding Sources 12018

\begin{tabular}{lrrr}
\hline \multicolumn{1}{c}{ Districts } & Villages & $\begin{array}{c}\text { Handling } \\
\text { (Unit) }\end{array}$ & $\begin{array}{c}\text { Nominal } \\
\text { (IDR Million) }\end{array}$ \\
\hline Banjarharjo & 25 & 75 & 750 \\
Bantakawung & 18 & 51 & 510 \\
Brebes & 18 & 46 & 460 \\
Bulakamba & 19 & 42 & 420 \\
Bumiayu & 15 & 39 & 390 \\
Jatibarang & 22 & 45 & 450 \\
Kersana & 13 & 36 & 360 \\
Ketanggungan & 21 & 63 & 630 \\
Larangan & 11 & 3 & 30 \\
Losari & 22 & 48 & 480 \\
Paguyangan & 12 & 36 & 360 \\
Salem & 21 & 63 & 630 \\
Sirampog & 13 & 33 & 330 \\
Songgom & 10 & 15 & 150 \\
Taanjung & 18 & 54 & 540 \\
Tonjong & 14 & 27 & 270 \\
Wanasari & 20 & 54 & 540 \\
amount & 292 & 730 & 7.300 \\
\hline SOurce: & 12 &
\end{tabular}

Source: Housing and Settlement Department Brebes Regency 
Central Java Provincial Government has a strong commitment to alleviate poverty through the synergy advance of the central government, provincial government and local governments. Significantly these efforts will be difficult to implement because the overall number of uninhabitable housing is very large. Therefore, researchers wanted to determine the effectiveness of rehabilitation assistance program uninhabitable housing Brebes 1 budget funding sources by 2018.

Based on this background the problem in this research are: 1) how the implementation of the distribution of aid rehabilitation of houses uninhabitable in Brebes sources of financing the budget 12018 and 2) bagaimanana effective aid programs rehabilitation of homes uninhabitable in Brebes sources of funding Budgets 1 tahub 2018. The objectives of this study were: 1) to assess the implementation of rehabilitation aid delivery uninhabitable housing Brebes budget funding sources 1 in 2018 and 2) to assess the effectiveness of rehabilitation assistance program uninhabitable houses in Brebes sources of funding Budgets 12018.

According Soerjono Soekanto (1982) in his Sociology, An Introduction to declare poverty is defined as a situation where a person is not able to care for itself in accordance with the standard of life of the group and also not able to take advantage of mental energy, and physical in resebut group.

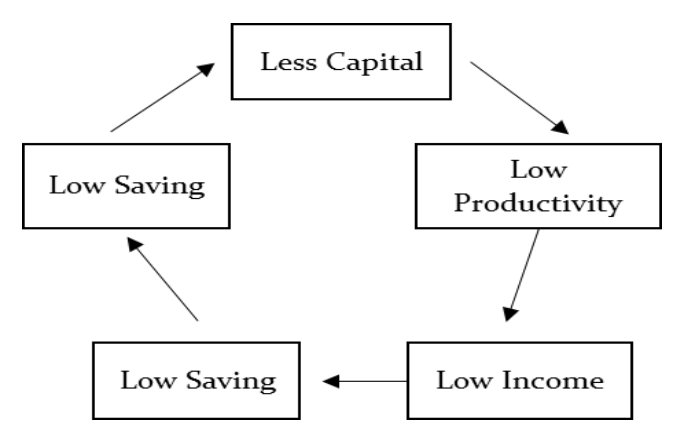

Figure 3. The vicious circle of poverty by Nurkse (1953)

Robbins and Judge (2008), described in a hierarchy of five basic human needs according to
Maslow, namely: 1) physiological needs (Physicological needs) include hunger, thirst, shelter, sexual and physical needs of others, 2) the need for security and safety (Security or safety needs) include curiosity protected from physical danger and emotional, 3) social needs (Affilation or acceptance needs) includes compassion, possession, acceptance and friendship, 4) esteem needs (Esteem needs) includes internal reward such as self respect, autonomy and pencapaianny as well as external factors such as the status of recognition awards and attention, 5) self-actualization needs (needs dor self-actualization), the urge to become a person in accordance skills include the achievement of one's potential growth and selffulfillment.

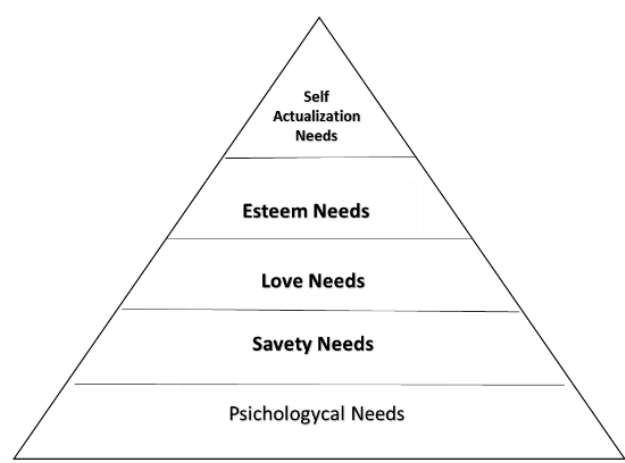

Figure 3. Maslow's Hierarchy of Needs

The house is a human physiological needs. The house has a great function for individuals and families. Not only just covers the physical value, but also mental and social. To support the house functions as a good physical condition then it must be fulfilled that is safe as shelter, mentally fulfill a sense of comfort and socially can maintain the privacy of family members. With the fulfillment of appropriate housing as one of the basic necessities of life is expected to achieve family resilience.

According to the regulations the Kementerian Pekerjaan Umum dan Perumahan Rakyat (KemenPUPR) in accordance with the Settlement and Regional Infrastructure Decree No. 403/KPTS/M/2002 and Permenpera No. $22 /$ Sweets/M/2008 for creating livable housing must consider various aspects. 
These aspects include the factors of health and safety aspects of the building. From the health aspect deemed appropriate shelter should be a location that is not affected by the floods and not humid. In addition, every room must meet the lighting and good air circulation. The presence of a functioning utility power network becomes an important point of the house livable. Each residential neighborhood should get power from minimum Perusahaan Listrik Negara (PLN) $450 \mathrm{VA}$. Then there are also street lighting. In addition to electricity, the presence of clean water from taps or from wells pump shall also be provided. Then, from the safety aspect of the home building must meet the technical requirements into account and the selection of appropriate materials. Part of the roof must have a slope which is adapted to cover materials used. The percentage of roof leaks that $<20 \%$ of the roof area of the house. While the floor must be made of material that is easy to clean, damp and strong to withstand bebean. To the bathroom walls must be at least 1.5 meters above the floor surface $20 \%$ of the roof area of the house. While the floor must be made of material that is easy to clean, damp and strong to withstand bebean. To the bathroom walls must be at least 1.5 meters above the floor surface. $20 \%$ of the roof area of the house. While the floor must be made of material that is easy to clean, damp and strong to withstand bebean. To the bathroom walls must be at least 1.5 meters above the floor surface.

The powerlessness of the poor to meet the needs of appropriate housing is directly proportional to the income and knowledge of the function of the house itself. Likewise, the issue of infrastructure and inadequate infrastructure could hinder the welfare of a family. Seedy environment and infrastructure is inadequate can lead to social and health problems.

Improving coordination of poverty reduction, the government publish the Presidential Regulation No. 15 Year 2010 on the Acceleration of Poverty Reduction which is a refinement of the Presidential Decree Number 13 Year 2009 on the coordination of Poverty in Pepres are mandated to form Tim Nasional Percepatan Penanggulangan Kemiskinan (TNP2K) at the central level whose membership consists of representatives from government, community, business, and other stakeholders. While at provincial and district/city formed Tim Koordinasi Penanggulangan Kemiskinan (TKPK) Provincial and Regency/City.

Implementation of a policy of course not independent of the various problems that exist, it can be seen based on the findings in the field along with the implementation of the rehabilitation program of financial bantuang uninhabitable houses still having some problems or concerns. So that the necessary measurements to determine the effectiveness of its success.

Popular science dictionary defines effectiveness as the accuracy of the use, effectiveness or support purposes. According to Campbell JP, measurement of effectiveness in general and the most prominent is the program's success, the success of the target, satisfaction with the program, the level of output and achieving the overall objectives. So that the effectiveness of the program can be run with the operational capability to carry out the work program in accordance with its intended purpose sevelumnya, comprehensively, efektivittas can be defined as the level of ability of an entity to be acted upon all the tasks principally atu to achieve the objectives predetermined (Cambell, 1990).

Beneficiary selection criteria rehabilitation of houses uninhabitable by Disperakim Central Java province includes the condition of the house include the floor area per capita of less than 10 $\mathrm{m}^{2}$, water sources are not healthy, do not have access to toilets, building materials are not permanent, does not have solar lighting and ventilation, no own division of space, and the lighting source instead of electricity.

RTLH target indicators according Disperakim Central Java province is the head of the household of childbearing age, including in low-income communities, never got home rehabilitation assistance from any party, people with disabilities, and people who have chronic illnesses.

Rehabilitation aid delivery mechanisms uninhabitable houses conducted by the Central Java Provincial Government, there are five 
stages. The first stage is the stage of the planning done by the village government through village meetings and making proposals. The second stage is the stage of liquefaction. The third stage is the stage of implementation. The fourth stage is the stage of monitoring and evaluation. If the implementation of the rehabilitation of houses has been completed, then proceed to the reporting stage governor of Central Java.

\section{RESEARCH METHODS}

This type of research used in this study is a survey method with quantitative approach and descriptive explanation. Survey method is a method of research methods to obtain the facts of the existing symptoms and seek factual particulars of a group or region. According Sugiyono (2003: 14) Quantitative research is a research method that is based on the philosophy of positivism, is used to examine the population or a particular sample. This Penelilitian descriptive approach with the aim to describe or give a picture of the object under study through data or samples that have been collected as is, without doing analalisis and make conclusions that are generally applicable.

The study was conducted during the period of June until the month of August in 35 villages in Brebes. The choice of location is based on the consideration of the suitability of the subject matter in the study also considered good data entry person, program, structure, and interaction in accordance with the needs of research. This location was chosen because of Brebes District is one district that goes into the red zone priority poverty reduction rehabilitation financial assistance uninhabitable houses in Central Java province.

The population is the totality of all individual objects that have certain characteristics, clear and complete to be studied. The population in this study are all beneficiaries uninhabitable housing rehabilitation in Brebes, amounting to 730 people. While the sample is part of the number and characteristics possessed by this population. When the population is too large and the investigation is not possible to learn all there is in the population, it is necessary sampling techniques for the research sample. The sampling technique in this study using techniques nonprobability sampling using purposive sampling. Nonprobability sampling is a sampling technique that does not give the opportunity and the opportunity for every member of the population to be selected into the sample (Sugiyono, 2012: 95). Purposive sampling method is sampling technique with consideration or criteria. According Suharsimi Arikunto (2010: 109), if the study population of less than 100 should be taken everything and if a large population or more than 100 people may have taken $10 \%-15 \%$ or $20 \%-25 \%$ or more. Of the population of this study were taken $13 \%$ of the sample was 100 people.

The data used in this study are primary data and secondary data. The primary data comes from interviews and questionnaires given to the respondent. Secondary data were obtained from two sources ie documents or other materials that are needed. In this study, secondary data obtained from Disperwaskim Brebes.

Instruments in this study is a questionnaire with Likert scale and rating scale. A questionnaire was used to direct interviews with respondents in order to produce an objective answer. Consideration is all respondents are lowincome and education level of respondents who mostly elementary school so difficult to understand the purpose of respondents feared the question when the questionnaire was deployed. In determining the required instrument quality test validity and test reliabelitas. To test whether each indicator invalid or can not do analysis using product moment correlation formula and formula alpha. Product moment correlation formula used to indicate the level of validity and legitimacy of an instrument.

Product Moment Correlation:

$$
r=\frac{n\left(\sum x y\right)-\left(\sum x\right) \cdot\left(\sum y\right)}{\left.\sqrt{ }\left\{\left(n \cdot \sum x^{2}\right)-\left(\sum x\right)^{2}\right\} \cdot\left\{n \cdot \sum y^{2}\right)-\left(\sum y\right)^{2}\right\}} .
$$

Source: Arikunto (2006) 
Where $\mathrm{r}$ is the correlation coefficient of grain; $\mathrm{n}$ is the number of respondents trial; $\Sigma \mathrm{x}$ is the number of scores in the distribution of $\mathrm{x} ; \Sigma \mathrm{y}$ the number of scores in the distribution $y$.

The decision to test is considered valid if the question items $r$ count $>r$ table items, and vice versa. Alpha formula is used to measure the same symptoms and the results obtained are consistent pengukuranny.

Alpha's Formula:

$\operatorname{Rac}=\left(\frac{k}{k-1}\right)(1-) \frac{\sum a b^{2}}{a t^{2}}$

Source: Ridwan (2009)

Where Rac is reliabelitas instruments; $\mathrm{k}$ is number of the questions; $\Sigma \mathrm{ab}^{2}$ is the amount of variance item; $\alpha \mathfrak{E}^{2}$ is variance matter.

Data collection techniques in this research was conducted through interviews with related parties ie the Head of Department of Housing and Settlements Brebes, questionnaires were distributed to beneficiaries uninhabitable housing rehabilitation, observation and documentation.

Once the data is acquired it is time for data processing. Data processing techniques in this research through a phase check (editing) the activities carried out by looking at the records of the information gathered data researchers, phase identification (coding), which classifies the data by providing identity in accordance with each category of each respondents, disclosure phase (tabulation), which processes input, organize and calculate data have been obtained.

Data analysis techniques in research using quantitative descriptive analysis or descriptive statistics. According Sugiyono (2003: 21) that is descriptive setatistik statistiik that serves to describe or give a picture of the object under study through a data sample or population as they are without doing the analysis and make conclusions apply to the public. From this research questionnaire data will be analyzed descriptively percentage with steps according to Ridwan (2004: 71-95) are as follows: 1) calculate the value of the respondent and each aspect or sub variabe, 2) recap value, 3) determine the interval value, 4) calculating the percentage formula, 5) determine criteria score to determine the percentage obtained descriptive type of each variable, The data analysis was conducted to gather facts and data about the study. Disclosure of facts and data is done in order to give an overview of various symptomsrelated to the research problem. Calculation using the formula interval as follows:

$\mathrm{I}=\frac{N T-N R}{K}$

Source: Hadi Sutrisno (1989: 421)

Where I is interval score; NT is the highest score; NR is low rating; $\mathrm{K}$ is class.

Furthermore, to determine the percentage of respondents using the following percentage formula.

$P=\frac{f}{n} \times 100 \%$

Source : Burhan Bunging (2010)

Where $\mathrm{P}$ is percentage; $\mathrm{f}$ is frequency of the answers obtained; $n$ is score the ideal answer.

\section{RESULTS AND DISCUSSION}

Brebes is one of the districts with the highest number of poor people in Central Java. The problem of poverty in Brebes never regardless of the condition of the vicious circle of poverty, limited conditions that cause poor can not meet the basic needs of life. Human needs are hierarchical means humans will meet the needs of the next higher after the previous requirements are met. This was disclosed by Abraham Harold Maslow in his theory of the hierarchy of human needs. Appropriate housing is a basic need that should be owned by every household. Because, in addition to being important as food and clothing needs of the home is the first place to grow kembannya family.

Central Java Provincial Government has a policy program one of which is the rehabilitation of homes uninhabitable. As said by Jadgish Bhagwatu (1998) in a previous study that poverty is the responsibility of the government entirely. The aid program uninhabitable housing 
rehabilitation has been carried out since 2016 which granted aid in the form of building materials worth IDR $10,000,000.00$ to each recipient.

Brebes in 2018 has implemented rehabilitation program uninhabitable houses of the provincial government sourced from a financial assistance fund budget 1. Policy rehabilitation assistance from the provincial government to Brebes awarded to three recipients residing in 292 villages in 17 subdistricts by optimizing cooperation mutual and self-help with the details as follows: a) all proposed data is data by name by address obtained from PBDT 2015 , b) beneficiaries RTLH proposed are the names in accordance with the criteria that have been approved and set in the village meetings and has been verified by the village, district, and county, c) RTLH aid funds can be used for operational costs and / or administration of the highest activity of $5 \%$ (five percent) of the budget ceiling.

From the results of data collection, obtained by the respondent characteristics and sex work profiles a sample of respondents. More than half of respondents have a livelihood as farm laborers that as many as 64 people, construction laborers totaling 10 people, artisan beca total of 11 people and more jobs as many as 15 people. This is in accordance with the geographical conditions Brebes predominantly majority work in agriculture. Characteristics of respondents by sex is the number of male respondents as many as 79 people and female respondents as many as 21 people.

Stages of rehabilitation aid delivery mechanisms uninhabitable houses in Brebes described in the technical guidelines contained in the Central Java Governor Regulation No. 48 of 2017. In the implementation, distribution of aid rehabilitation of houses uninhabitable in Brebes is not in accordance with the mechanism that has been determined. Among them are at the planning stage, there are several proposals beneficiary rehabilitassi uninhabitable houses in Brebes were returned to the beneficiaries because of the incompleteness of the content and error content of the proposals in accordance with the terms that Rencana Anggaran Biaya (RAB) and governmental decisions village chief on the establishment of implementing the activities, the minutes official results of consultation, site plan and village maps, photos $0 \%$ of the houses, and a statement of the village chief is solely responsible for the accuracy of the information. If the proposal is returned, and no repairs up to the limit specified time then the nominee deemed not to qualify for the next stage.

Time collecting proposals at the planning stage rehabilitation of homes uninhabitable in Brebes is March 1, 2018 to April 30, 2018. In addition, the liquefaction stage, there are as many as 4 respondents stated that they did not receive aid in the form of building materials, but in the form of money cash and some beneficiaries of successful researchers interviewed revealed that the material they receive is not from their own request and does not correspond to the needs of the village but have determined what a given material.

Whereas in the distribution mechanism, building meterial fully adapted to the needs of beneficiaries so that the recipient of the other beneficiaries obtain aid of different building materials. For building materials imported gradually at intervals of three days of the arrival of the previous material. Based on the mechanism, during the implementation phase of rehabilitation There is no monitoring of the parties related offices, but the respondents said that during the implementation phase to the rehabilitation home has been no implementation team revisit their homes. The last stage is the stage of reporting done at the latest on January 10,2019 . building meterial fully adapted to the needs of beneficiaries so that the recipient of the other beneficiaries obtain aid of different building materials. For building materials imported gradually at intervals of three days of the arrival of the previous material. Based on the mechanism, during the implementation phase of rehabilitation There is no monitoring of the parties related offices, but the respondents said that during the implementation phase to the rehabilitation home has been no implementation team revisit their homes. The last stage is the 
stage of reporting done at the latest on January 10,2019 . building meterial fully adapted to the needs of beneficiaries so that the recipient of the other beneficiaries obtain aid of different building materials. For building materials imported gradually at intervals of three (3) days of the arrival of the previous material.

Based on the mechanism, during the implementation phase of rehabilitation There is no monitoring of the parties related offices, but the respondents said that during the implementation phase to the rehabilitation home has been no implementation team revisit their homes. The last stage is the stage of reporting done at the latest on January 10, 2019. For building materials imported gradually at intervals of three (3) days of the arrival of the previous material. Based on the mechanism, during the implementation phase of rehabilitation There is no monitoring of the parties related offices, but the respondents said that during the implementation phase to the rehabilitation home has been no implementation team revisit their homes. The last stage is the stage of reporting done at the latest on January 10, 2019. For building materials imported gradually at intervals of three (3) days of the arrival of the previous material. Based on the mechanism, during the implementation phase of rehabilitation There is no monitoring of the parties related offices, but the respondents said that during the implementation phase to the rehabilitation home has been no implementation team revisit their homes. The last stage is the stage of reporting done at the latest on January 10, 2019.

The effectiveness of rehabilitation assistance program uninhabitable housing judged by certain criteria in achieving the goals of rehabilitation assistance program uninhabitable houses. As already researchers explain that the effectiveness in general and the most prominent is the appropriateness of the destination, precision targeting, satisfaction with the program, the level of input and output as well as the achievement of the objectives menyuluruh (Campbell, 1990) researchers took three criteria in assessing the effectiveness of that accuracy goal, target accuracy and satisfaction with the program.

Table 2. Recapitulation Rehabilitation Assistance Program Effectiveness Value Home Not Livable Brebes 2018

\begin{tabular}{llrrl}
\hline No & Variables & Score & \multicolumn{1}{c}{$(\%)$} & Category \\
\hline 1 & $\begin{array}{l}\text { Accuracy of } \\
\text { Purpose }\end{array}$ & 4028 & 55.94 & Ineffective \\
2 & $\begin{array}{l}\text { Target } \\
\text { Accuracy }\end{array}$ & 2354 & 84.07 & $\begin{array}{l}\text { Very } \\
\text { Effective }\end{array}$ \\
$\begin{array}{l}\text { Satisfaction } \\
\text { of the } \\
\text { program }\end{array}$ & 1851 & 57.84 & $\begin{array}{l}\text { Ineffective } \\
\text { Source }\end{array}$ \\
\hline
\end{tabular}

Source: Data Results

After analysis of the indicators of the effectiveness of the implementation of the rehabilitation program uninhabitable houses which include the accuracy of purpose, precision targeting, and satisfaction with the program on 100 respondents beneficiaries rehabilitation of houses spread across 35 villages in Brebes through a questionnaire, then the following is a recapitulation of the value of the effectiveness rehabilitation assistance program uninhabitable housing untu each variableDescription measure the effectiveness of rehabilitation assistance program uninhabitable houses in Brebes using three variables include the accuracy of purpose, target accuracy, and satisfaction with the program as follows.

Variables Destination accuracy used to determine whether the purpose of the rehabilitation program of financial assistance uninhabitable houses that have been implemented are appropriate and beneficial to the poor or not. To determine the value of the accuracy of purpose, in this study used two indicators, namely the establishment of appropriate housing and improved quality of life/health status of the poor. Both indicators are based on the criteria established by KemenPUPR.

From the calculation, there are 18 questions and obtained a score of 4028 with a value of percentage of $55.94 \%$ with category values are not equally effective in achieving the objective. 
This is evident from the condition of the building which is still largely a dirt floor, some parts of the house there is still a non-permanent wall made of wooden planks and grabag, as well as the condition of the roof most of the houses are still leaking during the rainy season.

In fact, when researchers conducted a survey found some respondents might not pick the condition of windows and doors. Such a condition is inversely proportional to livable housing criteria according to which the structure KemenPUPR roof construction, priggish and walls must meet the requirements of safety, security and comfort. Other than that, there are homes that do not have bathroom facilities and adequate latrines. There is still a bathroom and a toilet conditions of beneficiaries that are not covered. In terms of infrastructure there are homes that do not have a connection / flow of electricity in private. In fact, the utility power network is very important because it is needed for the daily life of residents.

This condition also occurs in other previous studies as performed by Rahmawati Zania (2018), that the achievement of program objectives were implemented included in the indicator is less effective because of a guarantee of appropriate housing has not been felt by the beneficiaries.

Variable satisfaction with the Program is aimed to know and learn the level of performance of government programs on a regular basis as a material for policies to improve the quality of the rehabilitation program of financial assistance uninhabitable houses in Brebes. Indicators of variable satisfaction with this program includes three terms on the terms of public satisfaction indicator indicator, which is the implementation of the program, and the growth of creative community participation. From the calculations, the score of 1851 with a percentage of $57.84 \%$ value value category of beneficiaries not satisfied with the program. This is evident from the majority of respondents said that the security and comfort of home still is not very good. Conditions are non-permanent walls, floors were still land, and the roof still leaked greatly affect the robustness of the construction of the house.
In addition, community participation around less towards the rehabilitation and understanding of beneficiaries of the requirements that must be completed is still not good.

It also happens to penelitiansebelumnya as on research conducted by Issabella, Jullios Fault, and Amaliatulwalidain (2014) in the district of Mesuji Way Serdang regency that there is a lack of community participation in assisting the rehabilitation around the house livable. However, different conditions occur in research conducted by Mandy Herath (2018), the satisfaction of the program is quite effective at for comfort and safety of home after rehabilitation for the better.

Variabael targeting accuracy used to determine whether a rehabilitation program uninhabitable houses that have been implemented given to beneficiaries who have the criteria in accordance with the provisions of the Department of Housing Settlement Region and Central Java. The indicators used in this variable is the poor who inhabit the house uninhabitable.

Variable target accuracy in this study showed very reach the target with a score of 2354 and a percentage of $84.07 \%$. This is evident from the condition of beneficiary households both in terms of economics, the feasibility of shelter, health meupun. Most households are beneficiaries of underprivileged families with heads of household earning less than IDR $500,000.00$.

Land ownership and house most of the beneficiaries is the property itself although there were some beneficiaries who do not have a certificate/letter of property rights as one of the requirements of beneficiaries is the ownership status of the land and the house is the property itself evidenced by the certificate, not signed and not in dispute (owned parent). In terms of feasibility of the house, mostly not in adequate condition the floor in the form of tnag, nonpermanent walls and roof in bcoor conditions. In addition, the availability of adequate sanitary facilities are also not yet proven by sebagiann households do not have toilet facilities.

This has happened in several other previous studies such as the studies conducted by 
Rahmawati Zania (2018) in Tegal that the beneficiaries are low-income poor people who inhabit the house uninhabitable. However, different conditions occur in research conducted by Mandy Herath (2015) found in his research that moment indicator classified as less effective at targeting accuracy due to the socialization carried out during the program will be run so that the accuracy of the target beneficiaries of the program are not achieved..

\section{CONCLUSION}

Pursuant to the results of research and discussion on the effectiveness of financial aid programs rehabilitation of homes uninhabitable in Brebes sources of funding Budgets 1 CE 2018 can be concluded as follows: 1) the results of the survey that was conducted there were the findings of the field that shows the distribution process of rehabilitation assistance from the government province to the recipient is not in accordance with the mechanism specified in the Governor Regulation No. 48 Year 2017. Among them are the beneficiaries did not receive aid in the form of building materials instead of cash, building materials that are not adapted to kebbutuhan beneficiaries and no implementation team reviewing back home early beneficiaries when the process of rehabilitation of houses to finish. 2) The calculation of the variable accuracy of the program's objectives to rehabilitate the house is not habitable Brebes 2018 funding sources Budgets 1 is said to not achieving the goal because of the condition of the building does not meet the criteria of appropriate housing according to KemenPUPR, 3) The calculation of variables of satisfaction with the program to rehabilitate the house is not livable Brebes 2018 funding sources Budgets 1 2018, said beneficiaries are not satisfied with the program for the safety and comfort of home that has not been good, 4) the calculation of variables appropriate targeting rehabilitation of houses uninhabitable Brebes 2018 funding sources Budgets 12018 is said to be the target is very appropriate. in addition to the need for community participation in assisting the rehabilitation around the house to remember one of the principles of this program is the mutual cooperation, 4) for the indicator target accuracy of the calculation, the results are very effective, which means appropriate targeting is appropriate target. The researchers suggest is that the government increase the number of beneficiaries for each year given the need for appropriate housing in Brebes still very much.

\section{REFERENCES}

Abraham H. Maslow. (2010). Motivation and Personality. Jakarta: Rajawali.

Agustino, L. (2008). Fundamentals of Public Policy. Bandung: Alfabeta.

Anderson, James E. (1994). Public Policy Making: An Introduction 7th Edition. Boston: Wadswoth.

Arikunto, Suharsimi. (2010). Research Management. Jakarta: Rineka Cipta.

Atmajha, Maullana Chandra. (2015). Evaluation of the Implementation of Inhabitable Home Rehabilitation Program as an Effort to Eradicate Poverty in Tanjung Pinang City. (online), (http://jurnal.umrah.ac.id/wpcontent/uploads/gravity forms / Journal -fixpdf, accessed 19 JUli 2019)

Bunging, Burhan. (2010). Communicative Quantitative Research Methodology, Economics and Public Policy and Other Social Sciences. Yogyakarta: Kencana.

Campbell. J. P., and Campbell, R. J. (1990). Productivity in Organization. San Francisco: Josey-Bass Publisher.

Dunn, William N. (2013). Introduction to Public Policy Analysis Second Edition. Yogyakarta: Gajah Mada University Press.

Dye, Thomas R. (1981). Understanding Public Policy. Englewood: Prentice Hall, Inc.

Hadi, Sutrisno. (1989). Research Methodology Volume III. Yogyakarta: Andi Offset.

Kartasasmita, Ginanjar. (1996). Community Empowerment: Development Concepts Rooted in Society. Yogyakarta: UGM.

Kuncoro, Mudrajat. (2010). Problems, Policies and Politics of Development Economics. Jakarta: Erlangga.

Pasolong, Harbani. (2010). Public Administration Theory. Bandung: Alfabeta. 
Person, Wayne. (2008). Public Policy: Introduction to Theory and Public Policy Analysis. Jakarta: Kencana Pernada Utama Media.

Prabawati, Beautiful. (2014). Implementation of Program Rumah Tidak Layak Huni (RTLH) in Kejuron Sub-District, Taman Kota Madiun District. Ejournal Unesa, Vol. 4 No 07. Surabaya State University.

Purnama, Syahrul Ramadhani. (2018). Evaluation of the Implementation of Communities Assistance for Inappropriate Houses in 20172018 in Tambun Utara District, Bekasi, West Java Province. Journal of Welfare StatE. University of North Sumatra

Ridwan. (2009). Application of Statistics and Research Methods. Jakarta: Salemba.

Rusdati and Lesta K.S, (2013). Factors affecting poverty in Central Java Province. Journal Economica, Vol 9 number 1 April 2013. Semarang State University.

Rusli, Budiman. (2017). The Coordination in the Implementation of the Unhabitable Home Improvement Program in West Bandung Regency. ASSEHR Vol 1412017.

Soekanto, Soerjono. (2009). Sociology: An Introduction. Jakarta: Rajawali Press.

Sugiyono, Prof. Dr. (2004). Non Parametic Statistics for Research. Bandung: Cv Alfabeta.

Sukirno, Sadono. (2006). Development Economics Second Edition. Jakarta: Salemba.

Spicker, Paul. (2002). Poverty and the Walfare State: Dispelling the Myths. Catalyst.

Sujarwani, Riau. (2016). Assesing the Impact of House Rehabilitation Program to Poverty Alleviation in Riau Island Province. Journal of Asian Review of Public Affairs and Policy, Vol 1 No 12016.
Suradi (2012). Social Policy Impact Evaluation Study: Rehabilitation of Uninhabitable Homes for Poor Families in Banjarmasin City. Journal of Socioconsepsia Vol 17 No 02.

Wahyuningrum, Tri and Indah Prabawati. (2017). Evaluation of the Rumah Tidak Layak Huni (RTLH) Rehabilitation Program in Kedungrejo Village, Balarejo District, Madiun Regency. UNESA Journal.

Weibowo, Rizki. (2014). Evaluative Study on the Implementation of Social Rehabilitation Program for Non-Habitable Homes (RSRTLH) in Improving Community Welfare in Pekauman Village, Tegal City. Journal of Pancasakti University.

Winarno, B. (2018). Scheme for Providing Livable Houses for the Poor in Belitung Regency. Journal of City Development. Vol 6 (1): 66-74. DOI: 10.14710 / JPK.6.1.66-74

Zania, Rahmawati. (2017). The Effectiveness of Social Assistance Programs for Non-Habitable Homes (BANSOS-RTLH) in Tegal City in 2017. (online), (http: //ejournal3.undip.ac.id.BANSOS-RTLHUndip. Diponegoro University e-journal accessed at 5 May 2019.

Zulhadi. (2013). Effectiveness of the Implementation of Social Rehabilitation Program for NonHabitable Homes in Poverty Alleviation (Case Study of the Social and Manpower and Transmigration Office of North Lombok Regency 2010-2012). (online), (http: // journal .usu.ac.id / index.php / ws) accessed on 10 May 2019. 